\title{
I. DÜNYA SAVAŞI SIRASINDA RUS DONANMASININ TRABZON VE ÇEVRESINII BOMBALAMASI
}

\author{
Hikmet ÖKSÜZ* \\ Veysel USTA $^{* *}$
}

\begin{abstract}
ÖZ
Osmanlı Devleti'nin Birinci Dünya Savaşı'nda mücadele ettiği cepheler içinde, geleceğe yönelik en ağır ve dikkate değer gelişmeler hiç kuşkusuz Kafkas Cephesi'nde meydana gelmiştir. Savaşın başlangıcıyla birlikte Rus donanması Osmanlı Devleti'nin Karadeniz'deki limanlarını ve kıyı şehirlerini bombalamaya başlamıştır. Kafkas Cephesi'nin çökmesi ve üstünlüğün Rus ordusuna geçmesiyle denizden ve karadan Rus ordusunun kıskacına giren Doğu Karadeniz Bölgesi, 1916-18 yılları arasında çok dramatik olaylara sahne olmuştur. Bunlardan en önemlisi bölge Müslümanlarının batı illerine doğru başlatmış oldukları kitlesel göç olayıdır. Bölgede "Muhacirlik" olarak adlandırılan bu dönem halkın sosyal hafızasında derin izler bırakmış ve sözlü kültürle günümüze kadar ulaşmıştır.

Ocak 1916'da Lazistan Sancağı kıyılarında başlayan Rus bombardımanı ve ardından yaşanan işgal, 18 Nisan'da Trabzon Vilayeti'nin merkez sancağı olan Trabzon şehrinin işgaliyle sonuçlanmıştır. Bu makalede, hem söz konusu süreçte yaşanan askeri harekât Rus ve Türk taraflarının kayıtlarıyla ele alınmış, hem de Trabzon Vilayeti kıyılarına yönelik Rus bombardımanlarının verdiği zayiatlar değerlendirilmiştir.
\end{abstract}

Anahtar Kelimeler: Trabzon Vilayeti, Lazistan Sancağı, Rus bombardımanı, muhacirlik, Rus işgali.

*Prof. Dr., Karadeniz Teknik Üniversitesi, Tarih Bölümü, hikmet61@ yahoo.com

** Okutman, Karadeniz Teknik Üniversitesi, Atatürk İlkeleri ve İnkılâp Tarihi Bölümü, veyselusta61@gmail.com 


\title{
THE BOMBARD OF THE RUSSIAN NAVY TO TRABZON AND ITS ENVIRONMENT DURING THE FIRST WORLD WAR
}

\begin{abstract}
The most significant and harmful events were existed in the Caucasus Front, apart from the other fronts in which the Ottoman Empire got into the struggle during the First World War. After beginning of the war, the Russian Navy started to bomb the Ottoman ports and towns in the Black Sea shore. After the collapse of the Caucasus Front for the Ottomans, Eastern Black Sea Region got under the control of the Russian army both in the sea and on land. Most dramatic events came into the scene during 1916-18. The most important one of these events was the mass migration of the Muslims from the region to the western cities. This era which was called Muhacirlik (being immigrant) left deep impressions in the social memory of the people and transferred to the present with oral culture.

The Russian bombard and invasion started at the seashore of the sancak of Lazistan in January 1916 and ended in April $18^{\text {th }}, 1916$ with the fall of the city of Trabzon, the center of the vilayet of Trabzon. In this paper, the military campaign was held according to the records of both the Russian and Turkish sides and also a consideration was made about the losses because of the Russian attacks to the shores of the vilayet of Trabzon.
\end{abstract}

Key Words: Vilayet of Trabzon, Sancak of Lazistan, Russian bombard, immigration, Russian invasion. 


\section{Giriş}

Osmanlı Devleti, henüz I. Dünya Savaşı başlamadan önce muhtelif ittifak girişimlerinde bulunmuştu. Ancak savaşın ve ittifakların ana planlaması çoktan kurulmuş bir düzen üzerinden yürütülüyordu. Sorun, paylaşım ve güç dengelerinde hassas ayarları yapmaktı. Nitekim Rusya, Osmanlı Devleti ile bir ittifaktan ziyade İngiltere'nin teklif ettiği boğazları ele geçirme planları yapmaktaydı. Bu plan İngiltere lehine başarılı olmuş, Rusya ve İngiltere, işbirliği sorununu çoktan halletmişti. Buna rağmen savaşın başlayacağı zamana kadar arayışlarını sürdüren Osmanlı Devleti; İngiltere, Fransa ve Rusya'dan istediğini alamayınca bu sefer Almanlara döndü. Pazarlıklar neticesini verdi ve 2 Ağustos 1914'te ise gizli ittifak anlaşması imzalandı. Kuşkusuz Almanların bu ittifakı gerçekleştirmesinde pek çok neden vardı, ancak bunların en etkili olanı Osmanlı Devleti'nin doğuda Rus kuvvetlerini gerek güç, gerekse zaman olarak oyalayabileceği düşüncesiydi.

Almanlar ve Osmanlı Devleti açısından en kötü senaryo ise Rusların İstanbul'u ele geçirmeleriydi. Almanlar için Rusların askeri ikmal işleri noktasında Karadeniz limanları önemli bir yere sahipti. Dönem itibarıyla savaş sürecinde deniz yollarının kara yollarından daha güvenli ve süratli olduğu gerçeği ortadaydı. Bu çerçevede Karadeniz'deki Rus deniz kuvvetinin etkisizleştirilmesi ya da en azından meşgul edilmesi oldukça önem arz ediyordu.

Hadiselere Karadeniz ve Trabzon özelinden bakıldığında Trabzon'un arz ettiği tarihi, coğrafi, stratejik, jeopolitik önem üzerinde durmakta fayda vardır. Zira Trabzon ve havalisi Rusların yayılma projelerinde genelde ilk adım, ya da atlama noktalarının başında geliyordu. Tarihsel süreçte benzer bir mücadelenin merkezinde bulunan Trabzon, İran'a uzanan ticaret ve askeri yolların denize açılma noktası idi. Aynı zamanda Ruslar için Karadeniz'in güneyindeki duraklarından biriydi. Nitekim Rusya güçlenip genişlediği tarihsel süreçte 1774'ten 1914'e kadar sürekli bir yayılma politikası gütmüş ve. 1914'e gelindiğinde Trabzon bu politikanın nihai hedefi olmuştur.

\section{Savaş ve Trabzon}

Birinci Dünya Savaşı'nın henüz başlarında, Osmanlı Devleti savaşa girmeden önce hükümet tarafından Trabzon'da bazı savunma tedbirleri alınmıştı. İlk girişim koruma bataryaları tesis etmekti. Ancak bu tedbirlerin tamamlanması mümkün olmadı. Savaş sürecinde ise III. Ordu'ya lojistik 
destek Trabzon üzerinden gerçekleşiyordu. Bu destek Yavuz, Midilli, Hamidiye gibi savaş gemileri ve sivil nakliye araçları ile sürdürülüyordu. ${ }^{1}$

Osmanlı Devleti, donanmasının 28-29 Ekim 1914 gecesi Rusya'nın Sivastopol ve Odesa limanlarını bombalaması ile fiilen I. Dünya Savaşı'na girmişti. Bu hadiseyi gerçekleştiren, Amiral Souchon komutasındaki Yavuz ve Midilli adı verilerek Osmanlı donanmasına katılan iki Alman zırhlısı, Karadeniz'deki kuvvet dengesini Osmanlı Devleti' nin lehine çevirememekle birlikte önemli bir psikolojik etki yaratmış ve 1853-1856 Kırım Savaşı'ndan sonra Rusya'ya yeniden saldırma cesaretini güdülemişti. Bu olay üzerine Rusya 2 Kasım'da, İngiltere ve Fransa 5 Kasım'da Osmanlı Devleti'ne savaş ilan ettiler. Osmanlı Devleti de bunlara 12 Kasım1914'te karşılık verdi.

29 Ekim baskınından sonra Ruslar, Osmanlı hükümetinin uzlaşma teklifini kabul etmemiş, Kafkas Ordusu, 1 Kasım 1914'te harekete geçmişti. Bir süre sonra Karadeniz sahilindeki Osmanlı şehirleri Rus savaş gemilerinin bombardımanlarına hedef olmaya başladı. Rus donanmasının hedefi Karadeniz'deki Osmanlı ticaretini ve bu sirada Trabzon üzerinden Kafkas Cephesi'nde mücadele eden III. Ordu'ya yapılan askeri nakliyat1 durdurmaktı. $^{2} \mathrm{Bu}$ maksatla yürütülen mayınlama ve bombalama faaliyetlerinin amacı Türk donanmasının çıkışına engel olmak, Karadeniz sahilinde kömür nakliyatını sekteye uğratmak ve Kafkas Cephesi'nin ikmalini engellemekti. Bu amaca yönelik olarak Rus donanması, esas olarak Zonguldak, Samsun, Akçaabat ve Trabzon limanlarını kendisine hedef seçmişti. Rus donanmasının Karadeniz sahillerinde yürütmüş olduğu bombardıman faaliyetlerinin Müslüman halkın moralini bozup göçe yönelmesini sağlamak, Pontusçu faaliyetlerin ve Ermeni tedhişinin zemin kazanmasını temin etmek gibi başka sebepleri de bulunmaktaydı.

Rusların bu ileri harekâtının en önemli kısmı ise karada cereyan etti. Ancak Osmanlı ordusu Rusları, başlangıçta Köprüköy muharebelerinde (612 Kasım 1914) durdurmuş, daha sonra geri çekilmeye mecbur etmiş̧i. Bu arada Azap-İlimi hattına çekilen Ruslara yeni destekler geldi. 14-18 Kasım 1914 tarihlerinde gerçekleşen Azap Muharebelerinde de Ruslar geri

1 İstanbul'dan iki uçak, bomba ve bir uçak bölüğü yüküyle hareket eden üç gemi Zonguldak'ta batırıldı. Sebahattin Özel, Milli Mücadelede Trabzon, Ankara 1991, s. 1-2; Enis Şahin, “İngiliz The Times Gazetesi’ne Göre Trabzon'un Ruslar Tarafından İşgali”, Uluslararası Karadeniz Incelemeleri Dergisi, S. 1, Güz 2006, s. 119-120.

2 Yavuz Özdemir, Bir Savaşın Bilinmeyen Öyküsü, Sarıkamış Harekâtı, Erzurum 2003. 
püskürtüldü. ${ }^{3}$ Rusların gücünün öngörülenden zayıf olduğunun anlaşılması üzerine Osmanlı Genelkurmayı tarafından Trabzon ve havalisindeki birliklere, Batum Limanı'nı ele geçirmek için emir vermiş ve bu yönde hazırlıklar başlatılmıştı. ${ }^{4}$

Karadeniz mücadelesinde 1914 yılı sonu ve 1915 başlarında BatumÇoruh bölgesindeki harekatlar kritik rol oynamıştır. Yukarıda da belirtildiği şekilde Rusların Kafkasya'daki ağır durumu, komuta kademesinde ciddi değişiklikler getirmişti. 25 Aralık 1914'te Kafkas ordularının kumandanı olarak General Vorontsov-Daşkov'un yerine General A.Z. Mışlayevski atandı. Fakat Ocak 1915'te artık Mışlayevski, Sarıkamış harekatının ilk safhasındaki başarısızlığın sorumlusu olarak görüldü ve görevden alındı. 6 Şubatta yerine, o zamana kadar 2. Türkistan Kolordusu kumandanının sorumluluğunu üstlenmiş olan GeneralYudeniç atand. ${ }^{5}$

Savaşın başlarında Batum'da, Rus savaş gemilerinden sadece torpido gemisi Dihtau ve askeri nakliye gemisi Berezan bulunuyordu. Kasım'ın ilk günlerinde buraya kömürlü torpido gemisi Jarkiy, Aralık ortasında ise torpido gemisi Jivuçiy yönlendirilmişti. Daha sonraları sözkonusu filoya, torpido gemisi Svirepiy de eklenmişti. Bu gemiler, Batum askeri birliğinin deniz kanadını topçu ateşiyle desteklediği gibi Osmanlı donanmasına mensup gemilerin Karadeniz'deki faaliyetini önleme çalışması da yapıyordu. Çok kısa bir süre sonra, Ocak 1915'te Batum'a, 5. mayın bataryası transfer oldu; bunlar yukarıda bahsedilenlerle aynı tipte olan Zorkiy, Zavidnıy, Zavetnıy, ve Zvonkiy idi. Bu gelişmelerden sonra Türk filosunun Kafkas ordusunun kıyı kanadına yönelik ileri yürüyüş operasyonları geçici olarak kesilmişti. $^{6}$

Öte yandan Alman Yarbay Ştange ile Dr. Bahattin Şakir ve Acaralı Rıza Bey komutasındaki Teşkilat-1 Mahsusa birliklerinin Batum'a yönelik saldırı hazırlıkları, burada ciddi bir paniğe yol açmış, Ruslar başarısız buldukları Sahil Müfrezesi Komutanını değiştirme ihtiyacı hissederek bu göreve General Liyahov'u atamışlardı. ${ }^{7}$ Böylelikle yeniden yapılanan Rus sahil müfrezesi, Türk saldırılarına karşı ileri harekâta başlamıştı. Amaç,

\footnotetext{
${ }^{3}$ Rusların ilk ilerlemesi 4 grup halinde gerçekleşmiştir. Bunlar İstomin Tugayı, Sarıkamış Grubu, 1. Plaston Tugayı, Erivan Müfrezesi idi. Fevzi Çakmak, Büyük Harpte Şark Cephesi Harekatı, İstanbul 2011, s.40-56.

${ }^{4}$ Mehmet Bilgin,Rus Işsgalinde Trabzon Direnişi, Trabzon 2008, s. 23.

${ }^{5}$ V. Gonçarov, Deystviya Primorskogo Otryada Kavkaskoy Armii, Ast-tranzitkniga, Moskva 2004, s. 665.

${ }^{6}$ Gonçarov, a.g.e., s. 666.

${ }^{7}$ Bilgin, a.g.e., s. 24.
} 
Erzurum civarlarında devam eden kara savaşlarına Trabzon üzerinden yapılan ikmali tamamen kesmek ve Rus ordusuna destek sağlamaktı. Bu bağlamda, Türk ordularının tedariklerinin yönetildiği Rize Limanı'nın ele geçirilmesi ilk hedef olarak öngörülmüştü. ${ }^{8}$ Bunun için harekete geçirilen İmparatoriçe Maria ve Katerina savaş gemileri, Rusların sahil çıkarması için koruma görevi yapacak ve iki kolorduyla Trabzon'a çıkarma yapılması temin edilecekti. Ancak bu çıkarmanın ilk ayağı Rize olacak, buraya yerleşildikten sonra kara kuvvetleri takviye edilerek Trabzon üzerine yürünecekti. ${ }^{9}$

10 Ocak 1916'da, sahil bölgesinde, Arhavi Deresi boyunca, 11 tabur piyade, 3 bölük süvari ve 24 topu olan Rusların karşısında, Türklerin 7 tabur piyade, 1 takım süvari ve 6 toptan oluşan Sahil Müfrezesi vardı. ${ }^{1016}$ Kara ordusunun Erzurum üzerine yeniden taarruza geçmesinden bir hafta önce Ruslar, sahil bölgesinde de saldırıya geçmişlerdi. ${ }^{11}$ Türk tarafında, coğrafyanın sağladığı üstünlük, Rusların ağır toplardaki kayda değer gücü nedeniyle kısa sürede tersine dönmüştü. 4 Şubat sabahı Rus donanmasına bağlı Rostislav gemisi, 6 mil $(11 \mathrm{~km})$ uzaklıktan $254 \mathrm{~mm}$ 'lik toplarla Türk bataryasına ateş açtı ve çabucak etkisiz hale getirdi. Türk mevzileri ve bataryalarının ateşten etkilenmemek üzere yer değiştirmesini fırsat bilen Rus kuvvetleri, öğlen civarında Arhavi'ye çıkarak nehrin batı kıyısında konuşlandı. İlk çıkarmanın yapıldığı gün Rus kuvvetlerinin kullandığı mühimmat şöyle idi: ${ }^{12}$

\begin{tabular}{|l|l|}
\hline Kalibre & Sayı \\
\hline $254 \mathrm{~mm}(10 ")$ & 94 \\
\hline $152 \mathrm{~mm}(6 ")$ & 388 \\
\hline $120 \mathrm{~mm}$ & 27 \\
\hline $75 \mathrm{~mm}$ & 122 \\
\hline
\end{tabular}

${ }^{8}$ Gonçarov, a.g.e., s. 666.

${ }^{9}$ Çakmak, a.g.e., s. 241

${ }^{16}$ Çakmak, a.g.e., s.138. Gonçarov, Rus ve Tür ordularının askeri durumunu şöyle vermiştir: Rusların 10 piyade taburu, 3,5 süvari birliği ve 9 yerel muhafız birliği bulunuyordu, 38 ağır top ile beraber tamamı yaklaşık 1.500 kişi idi. Türk güçleri buna sayıca 10 ağır top yanında 14 piyade taburu ile karşı koyuyordu. A.g.e., s. 666.

${ }^{11}$ Bilgin, a.g.e., s. 31.

${ }^{12}$ Gonçarov, a.g.e., s. 667. 
Arhavi'de tutunan Rus birlikleri, Türk siperlerine yönelik donanmalarından aldıkları yoğun ateş desteğinin de yardımıyla 7 Şubat'ta Ardeşen'e ilerlediler. Devam eden Rus taarruzları sonucu, 13 Şubat'ta Fındıklı Deresi'nin batı yakasına çekilen Türk kuvvetleri, 15 Şubat'ta gün boyunca denizden donanmanın bombardımanla desteklediği Rus taarruzlarına karşı direniyordu. ${ }^{13}$

15/16 Şubat gecesi, Rusların beklemediği bir sırada Türk kuvvetlerinin düzenlediği gece taarruzu, bir süreliğine Rus deniz birliklerine üstünlük sağlamış olsa da sabaha doğru geri çekilmek zorunda kalmışlardı. ${ }^{14}$ Nitekim kesin bir sonuç alınamayacağ 1 görülünce birliklerimiz geri çekilmeye başladı ve 19 Şubatta Büyükdere-Fırtına Deresi hattının batı yakasında yeni bir savunma mevzisi oluşturuldu. ${ }^{15}$

Rusların çıkarma yaptıkları yöreleri koruyabilmeleri ve Türk birliklerinin bu bölgelere yönelik yeni bir karşı saldırı gerçekleştirmesini engellemek üzere Rus donanmasına yeni takviyeler yapıldı. Uzun menzilli toplara sahip olan Rus donanmasınca Türk siperleri aralıksız taciz ateşine tutuluyordu. Sik sik Batum ve Sivastopol limanlarından takviyeler alan Rus donanmasının ateş üstünlüğü altında ilerleyen kara birlikleri 7 Mart'ta Rize'ye girmeyi başardılar. ${ }^{16}$

\footnotetext{
${ }^{13}$ Bilgin, a.g.e., s. 31.

${ }^{14}$ Gonçarov,a.g.e., s. 667.

${ }^{15}$ Bilgin, a.g.e., s. 31.

${ }^{16}$ Gonçarov, a.g.e., s. 668-669.
} 


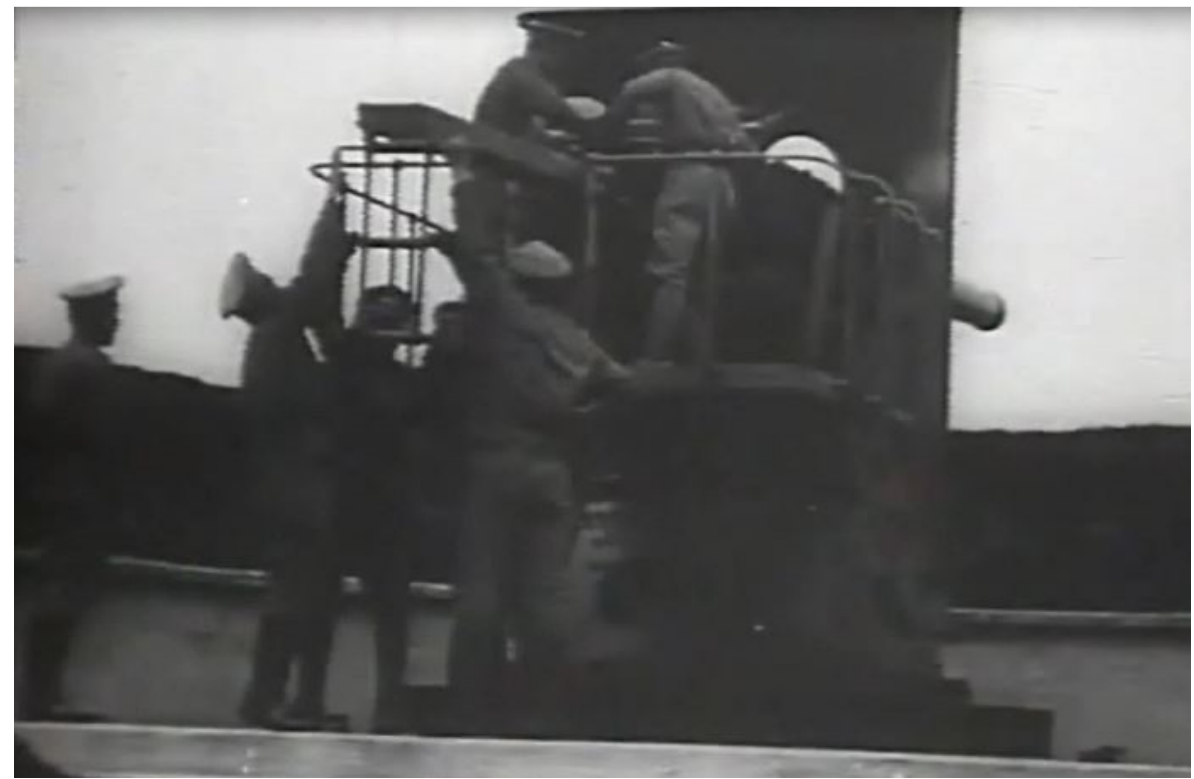

Uzun menzilli Rus gemisinden Türk siperlerinin bombardımanı

Rus harekatının temel stratejilerinden biri olan Rize Limanı'nın ele geçirilmesi ve burada orduya yapılan takviyelerden sonra 19. Türkistan Alayıyla saldırıya geçen Ruslar, denizden Panteleimon Zırhlısı ve 6 muhrip ile Türk siperlerini yoğun ateş altına aldı. 26 Mart’ta başlatılan saldırı, aynı gün akşamına doğru Of'un işgal edilmesiyle neticelendi. ${ }^{17}$ Hızını kesmeden ileri harekata devam eden Ruslar, dört günlük bir süre sonunda 1 Nisan'da Homurgan'1 (Eski Sürmene merkezi) işgal etmişti. ${ }^{18}$ Aynı gün bir Türk denizaltısı tarafından, Rusların Portugal adlı gemisi, hastane işareti taşımasına rağmen silah ve mühimmat nakli yaparken batırıldı. ${ }^{19}$

Karadere savunma hattına dayanan Rus kuvvetleri, Türklerin yaklaşık 14.000 kişilik askerle ciddi bir savunma hattı oluşturduğu bu yerde ${ }^{20}$, Ruslar için doğal zorlukla da karşılaşınca Novrosisk'ten destek beklemek zorunda kalmışt1. ${ }^{21} \mathrm{Bu}$ süre içinde Rus ordusunun sayısı 32.500 'e ulaşmış, donanması ise iki savaş gemisi, iki hücum botu, 8 torpido gemisi, 8 LPD-4 tipi mayın

${ }^{17}$ Çakmak, a.g.e., s. 253.

${ }^{18}$ Gonçarov, a.g.e., s. 679.

${ }^{19}$ Çakmak, a.g.e., s. 253.

${ }^{20}$ Gonçarov, a.g.e., s. 680.

${ }^{21}$ Çakmak, a.g.e., s. 253. 
temizleyici ve devriye botları ile bir hayli güç kazanmıştı. ${ }^{22}$

14 Nisan'da yeniden saldırıya geçen Rus ordusuna destek olmak üzere, Rostislav ve Panteleimon, kıyıya 12 palamar (yaklaşık 2 kilometre) yaklaşıp, makinelerini durdurarak 6 inçlik toplarla Kara Dere'nin sol kıyısında ve yumuşak bir tepenin yamacında bulunan Türk yerleşimlerine, ayrıca Sürmene kasabasına ve Araklı burnuna ateş açtılar. Bu bombardımandan yaklaşık bir saat sonra taarruza geçen Rus güçleri Türk direnişini kırdı. ${ }^{23}$

14 Nisan günü öğlene doğru, Karadere'deki Türk savunma mevzilerini yaran Ruslar, 15 Nisan'da Yanbolu Deresi'ni geçmiş ve 16 Nisan'da Yomra'ya varmışlardı. 15/16 Nisan gecesi Trabzon şehri Türkler tarafından boşaltılırken, şehirde sadece Rum ve Ermeniler kalmıştı. Karadere'den çekilen birliklerimizden Teşkilat-1 Mahsusa Alayı, Giresun ve Trabzon Jandarma Alayları batıya, 28. Alay Değirmendere Vadisi'nden güneye, Maçka istikametine çekilmiş, Hortokop sırtlarında savunma mevzileri oluşturmuştu.

Rus saldırısı sırasında Aho Dağı'nı savunan birliklerimiz mevzilerini kahramanca müdafaa etmiş ve Aho Dağı'nın zaptı, Ruslara 1000 ölüye mal olmuştu. ${ }^{24}$ Nihayet Rus birlikleri 16 Nisan'da Yomra'da Kalafka Deresi'ni ele geçirdiler. Şimdi sıra Trabzon'un işgaline gelmişti, ancak bu şerefi kendisine mal etmek isteyen General Liyahof, artık donanmaya ihtiyaç kalmadığg gerekçesiyle zırhlıları Sivastopol'a geri göndermişti. ${ }^{25}$

${ }^{22}$ Gonçarov, a.g.e., s. 682-683.

${ }^{23}$ Gonçarov, a.g.e., s. 684-685.

${ }^{24}$ Bilgin, a.g.e., s. 45.

${ }^{25}$ Çakmak, a.g.e., s. 257-258. 


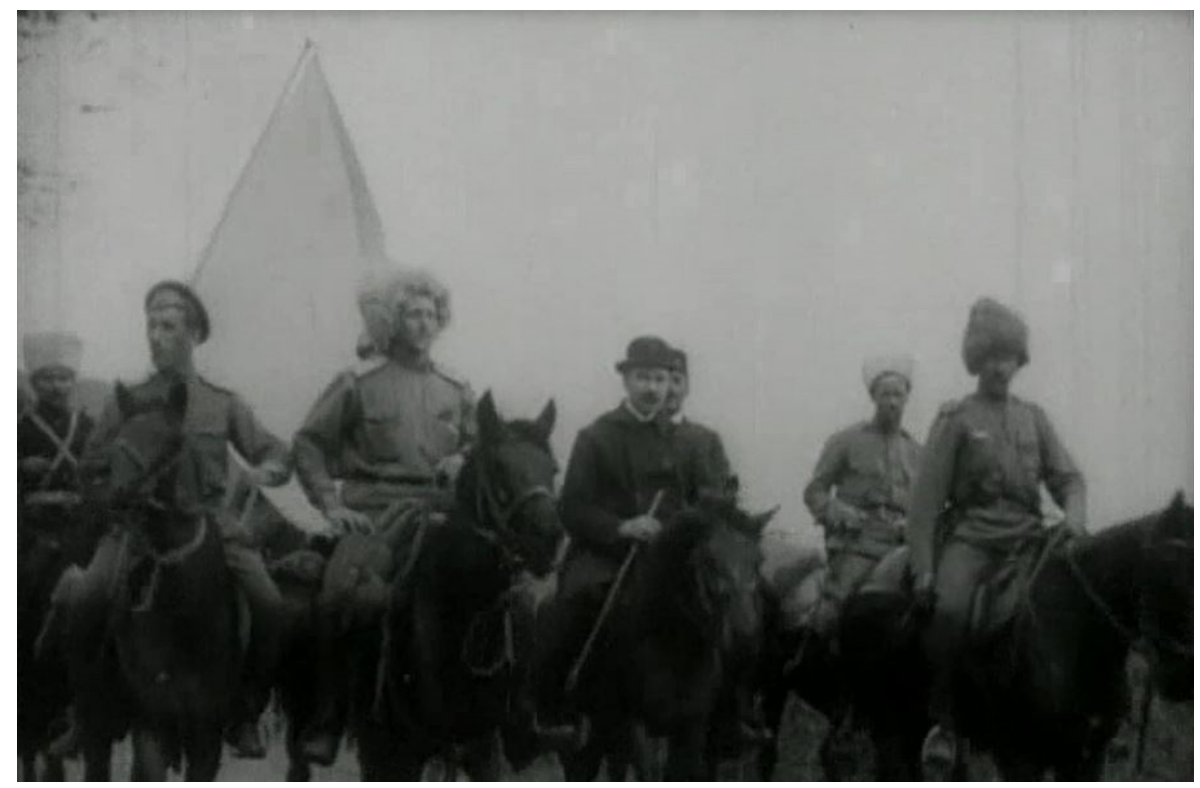

Yomra'da konuşlanan Rus ordu karargahına giden ve aralarında A.B.D'nin Trabzon Konsolosu Heizer'in de bulunduğu heyet

15 Nisan 1916'da Trabzon'a 18 km. kadar yaklaşan Ruslar, Türk kuvvetlerini arkadan vurmak için Akçaabat'a çıkarma yapmak üzereyken Trabzon'un boşaltılmış olduğunu haber almışlardı. ${ }^{26}$ Zira, beklenmedik bir şekilde Rus saflarına ulaşan Trabzonlu Rumların temsilcilerinden oluşan bir grup, Türklerin şehri terk ettiğini, dolayısıyla Rusların herhangi bir çatışma olmaksızın şehre girebileceklerini bildirdiler. ${ }^{27}$ Şehir 15/16 Nisan akşamı tahliye edilmiş, Türk halkının büyük bir kısmı şehri terk etmişti. ${ }^{28}$ Rus ordusunun deniz müfrezesinin Trabzon'a girmesiyle birlikte kıy boyunca uzaklaşan Türklerin gözetlenmesi için donanmaya ait kruvazörler ve torpido gemileri görevlendirilmişti. Türkler tarafından mayınlanan liman ve çevresinin temizlenmesinden sonra Rus donanmasına ait gemilerden oluşan destek birlikleri de burada konuşlandırılmıştı. ${ }^{29}$

Trabzon'un işgalinden sonra, bir yandan sahil boyunca AkçabatVakfıkebir istikametinde ilerleyen Rus kuvvetleri, 19 Nisan'da güneye doğru ilerleyerek Cevizlik'e girmiş, yan ve gerilerini korumak üzere Gümüşkihan-

\footnotetext{
26 Özel, a.g.e.,s . 6.

${ }^{27}$ Gonçarov, a.g.e., s. 684.

28 Özel, a.g.e., s . 6.

${ }^{29}$ Gonçarov, a.g.e., s. 684.
} 
Madur hattına kadar ilerlemişlerdi. ${ }^{30}$

Böylelikle, 1461'de Fatih Sultan Mehmet tarafından Rum Devleti'nin yıkılmasıyla Türklerin egemenliğine giren Trabzon, yüzlerce yıllık bir aradan sonra işgale uğramış ve Rus Çarlığı'nın kontrolü altına girmişti. Trabzon bölgesi komutanlığına atanan Alman asıllı Rus Generali Şvartz; Rusça, Rumca ve Türkçe bir bildiri yayımlayarak Trabzon'da Rus kanunlarının uygulanacağını, bütün eski düşmanlıkların unutulması gerektiğini, kanunlara karşı gelenlerin şiddetle cezalandırılacaklarını ilan etti. İşgalle birlikte yüzyıllar önce Türkler tarafından camiye çevrilmiş olan eski kiliselerde namaz k1lınması yasaklandı ve binalar Rumlara verildi. ${ }^{31}$

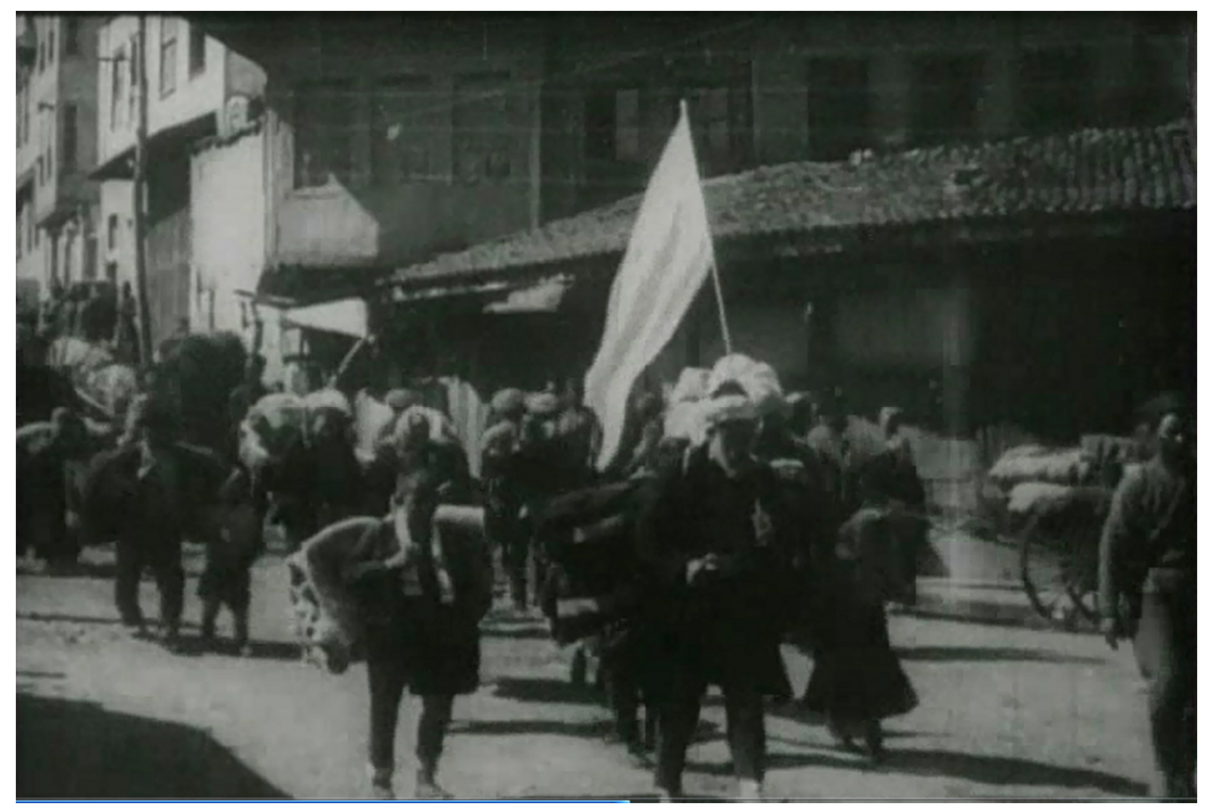

Müslüman Türklerin Trabzon'u terk ederek batıya doğru muhacirliğe çımaları

${ }^{30}$ Çakmak, a.g.e., s. 258.

${ }^{31}$ Mahmut Goloğlu, Trabzon Tarihi, Trabzon 2013, s. 226-227. 
Trabzon'un işgali, Rusya'nın müttefiki olan İngilizlerin Manchester Guardian gazetesine şu manidar ifadelerle yansımıştı: ${ }^{32}$

“San Stefano Antlaşması'nın 19. Maddesine rağmen Rusya Karadeniz sahilinde kırk millik alanı ve içerdeki 20.000 mil karelik alanı ele geçirdi. Rusya'nın gözü sürekli olarak Mithridates'in eski başşehri olan, kendine özgü konumundan dolayı ve siyasi, coğrafi, tarihsel olarak ünlü bir şehir olan Trabzon'un üzerinde idi."

İfadelerden, bir yandan Rusya'nın Ayastefanos Antlaşması'na aykırı olarak yayıldığına işaret edildiği tespit edilebileceği gibi, öte yandan müttefikleri olan Rusya'nın düşmanları olan Osmanlı Devleti'ne karşı kazandığı zaferden memnuniyet duyulduğu da anlaşılabilmektedir. Aynı gazetenin, Trabzon'un işgalinden iki gün sonra yayımlanan nüshasında ise Trabzon'un işgalinin Almanları ciddi şekilde endişelendirdiği, zira bu gelişme ile Anadolu coğrafyası üzerindeki Alman nüfuzu hayallerinin sona erdiği ifade edilmektedir. ${ }^{33}$

\section{Bombardımanlar Sonucunda Ortaya Çıkan Zayiat ve Alınan Tedbirlerden Bazı Örnekler}

Akdeniz'de İtilaf Devletleri donanmasının ününden kaçarak İstanbul'a sığınan iki Alman gemisinin Yavuz ve Midilli adını almasından bir süre sonra Karadeniz'e açılarak Rus limanlarını bombalanması üzerine misilleme yapmak üzere Karadeniz'e açılan Rus donanması birçok kıyı şehrini ve Türk limanlarını bombalamaya başlamıştı.

Rus donanmasının Karadeniz' deki ağırlığı ise Kasım 1914'ten itibaren iyice hissedilmeye başlanmıştı. Bu ağırlığın odak noktasını ise Trabzon teşkil ediyordu. Yavuz ve Midilli'nin Rus limanlarını bombalamasından sonra, Karadeniz'deki kontrolü ele geçirmek ve Osmanlı ordusunun ikmal imkanını engellemek isteyen Rusların, İstanbul'dan iki uçak, bomba ve bir uçak bölüğü yüküyle hareket eden Bezmialem, Bahriahmer ve Mithatpaşa gemilerini 6 Kasım 1914'te Zonguldak önlerinde batırmas1, Osmanlı Donanmasının Karadeniz'deki etkinliğini büyük ölçüde ortadan kaldırmıştı. ${ }^{34} 19$ Kasım'da ise Trabzon ve çevresindeki kıyıları bombalayan Rus donanması, giriş çıkışı engellemek üzere Trabzon Limanı'nın önünü de

${ }^{32}$ Manchester Guardian, 3 Nisan 1916, s. 10.

${ }^{33}$ Manchester Guardian, 20 Nisan 1916, s. 14.

${ }^{34}$ Özel, a.g.e., s. 3. 
mayınlamıştı ${ }^{35}$ Dönemin tanıklarından Mustafa Reşit Tarakçıŏlu hatıratında Rusların Trabzon'a yönelik bombardımanını şöyle aktarmaktadır: ${ }^{36}$

"Sivastopol ve Batum bombardımanlarının acılarını çıkarmak için Ruslar ilk önce 17 gemi ile Trabzon şehrini ateşe verdiler. Bu bombardımanda Murathanoğlu Hasan Beyin, Çulhaoğlu Hacı Kadir Efendinin konakları yıkılıp yandılar; şehrin Kemerkaya ve Meydan mahallelerinde evler yıkıldl, yangınlar çıtı. Şirin Hatun (Yavuz Sultan Selim'in üvey annesi) Mahallesinin sübyan (çocuk) mahalle okulunun öğretmeni Halim Efendi ile hanımı ikindi namazlarını kılmaktalar iken evlerine düşmüş olan bir Rus mermisi ile her ikisi de şehit oldular. Savaş yıllar boyunca Rus donanmast Karadeniz sahillerini, Trabzon, Giresun, Ordu, Samsun, Zonguldak, Rize ve dolayların ardı arkası kesilmeyen top ateşine tuttular."

Diğer bir tanık olan Muzaffer Lermioğlu ise Trabzon'da ilk Rus bombardımanının 17 Kasım 1914 tarihinde gerçekleștiğini, ancak bunun daha çok gösteri (korkutma) amaçlı olduğunu, özellikle resmi binaların hedef alındığını vurgulamaktadır. Deniz fenerine atılan mermiler hedefine isabet etmemiş, Güzelhisar'daki bazı mağazalar ise tahrip edilmişti. İlk mermi, Tuz Gümrük binasına isabet ederek binayı yıkmış, Çömlekçi Mahallesi'nde bir kısım evlerle, eski postane binası ve Cihan Oteli kısmi zarara uğramış, diğer mevkilerde bazı evler yanmış ve yıkılmıştı. Bu ilk bombardımanında isabet alarak tahrip olan binalardan biri de Rus Konsoloshanesi idi. Bir gemi tarafından iki saat süren bu bombardımanda 48 sivil ölmüş ve on ağır yaralı hastaneye kaldırılmıştı. ${ }^{37}$

\footnotetext{
${ }^{35}$ Bilgin, a.g.e., s. 23.

${ }^{36}$ Hikmet Öksüz-Veysel Usta, Mustafa Reşit Tarakçıŏglu, Hayatı, Hatıratı ve Trabzon'un Yakın Tarihi, Trabzon 2008, s. 123.

${ }^{37}$ Muzaffer Lermioğlu, Akçaabat- Akçaabat Tarihi ve Birinci Genel Savaş - Hicret Hatıraları, İstanbul 2012, s. 225.
} 
Aralık 1914'te Trabzon'dan dönmekte olan Derince Vapuru Yoroz Burnu açıklarında Rus savaş gemileri tarafından batırılmıştır. Bir kısım mürettebat esir düşmüş, pek çok kişi ise kurtarılmıştır. Konuyla ilgili Tirebolu Komiser Muavinliğinin verdiği bilgilere göre 13 Aralık 1914 tarihinde saat dört buçukta Trabzon'dan hareket eden Derince Vapuru, Yoroz Burnu'ndan tahminen kırk beş mil açıkta dört adet Rus torpidosuna rastlamış, vapurun adı sorulduktan sonra bir torpil atılmış ise de Derince Vapuru isabet almamıştır. Ardından, vapurdan ikinci kaptanla, tercüman ve iki tayfa sandalla torpidolara giderken bir sandalın geldiğini görmüş ve gelen kişiler kaptanla iki tayfayı esir alarak tercümanı vapura geri göndermişlerdir. Ruslar diğer mürettebat ve yolcuların on dakikaya kadar vapuru tahliye etmelerini teklif etmişlerdir. Hemen ardından yolcular üç sandala bindirilmiş ve vapur Ruslarca batırılmıştır. Daha sonra sandalda bulunan şahıslara kendilerini takip etmeleri söylenmişse de Rus torpidoları Batum istikametine giderek gözden kaybolmuştur. Bu esnada sandaldakiler yolu şaşırarak 16 saat kadar deniz üzerinde kalmış, 14 Aralıkta salimen Tirebolu'ya çıkabilmişlerdir.

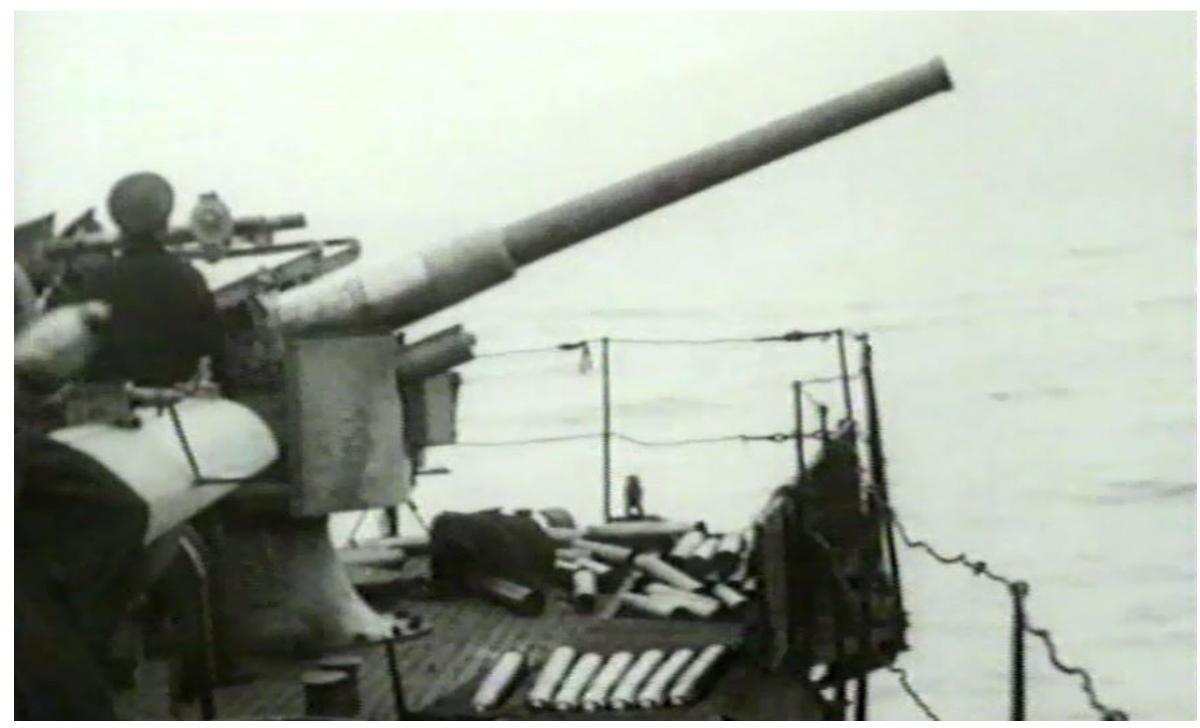

Türk askerlerinin kontrolündeki Arhavi ve köylerinin denizden bombardımanı 
Trabzon Polis Müdüriyetinden verilen bilgilere göre Derince Vapuru'ndan kurtulanların isimleri şu şekildeydi: ${ }^{38}$

\begin{tabular}{|c|c|}
\hline (9) & $(25)$ \\
\hline 1 Mülazım-1 Sani Mehmed Nazmi Efendi & 1 Hacı Lütfullah Oğlu Ahmed Rize \\
\hline 1 İbrahim Oğlu Dursun & 1 Kasaroz Oğlu Mehmed Rize \\
\hline 1 Süleyman Oğlu Ferhad Atina & 1 Mustafa Oğlu Hayri Rize \\
\hline 1 Ali Oğlu Mustafa Görele & 1 Halim Oğlu Süleyman Rize \\
\hline 1 Ömer Oğlu Ali Osman Görele & 1 Ali Oğlu Halil Rize \\
\hline 1 Halil Oğlu Bilal Görele & 1 Haşim Oğlu Akif Rize \\
\hline 1 Tafar Oğlu Hüseyin Dersaadet & 1 Haşim Oğlu Mehmed Vakfıkebir \\
\hline 1 Emin Oğlu Haydar Yomra & 1 Mustafa Oğlu Hüseyin Yomra \\
\hline 1 Ali Oğlu Hüseyin Tirebolu & 1 Abdülhamid Yomra \\
\hline Ahiran Tahlis Edilen (2) & 1 İsmail Oğlu Şakir Yomra \\
\hline 1 Muhiddin Bin Mahmud Şam-1 Şerif & 1 Hüseyin Oğlu Aşıki Yomra \\
\hline 1 Mehmed Cuma Bin Hacı GasılHaleb & Erzurum’a Para Götürenlerden (3) \\
\hline Efrad-ı Cedide-i Bahriyeden (14) & 1 Ömer Oğlu Mehmed Diyor Bey \\
\hline 1 Salih Oğlu Mustafa Tonya & 1 Ahmed Oğlu Tevfik Kastamonu \\
\hline 1 Mehmed Oğlu Mustafa Rize & 1 Mustafa Oğlu Hüseyin Kastamonu \\
\hline 1 Hüseyin Oğlu Mustafa Akçaabad & Vapurun İşaretçilerinden (2) \\
\hline 1 Hüseyin Oğlu Mehmed Vakfıkebir & 1 Mülazım-1 Evvel İsmail İzzet Efendi \\
\hline 1 Rüstem Oğlu Fahri Atina & 1 Osman Oğlu Hızır Der Saadet \\
\hline 1 Mahir Oğlu Hasan Atina & Vapurun Mürettebat ve Süvarileri Alman (23) \\
\hline 1 Mecid Oğlu Hasan Atina & 1 Süvari Şinayder \\
\hline 1 Receb Oğlu Mesud Atina & 1 Üçüncü KapudanŞalayder \\
\hline 1 İsmail Oğlu Hüeyin & 1 Çarhçı Başı Fon Ravon \\
\hline 1 Ahmed Oğlu Halil & 1 İkinci ÇarhçıRasin \\
\hline 1 Osman Oğlu Kemal Rize & 1 Üçüncü ÇarhçıVins \\
\hline 1 Yusuf Oğlu Rıdvan & 1 Vapurun Tercümanı \\
\hline 1 Muharrem Oğlu Mustafa & 17 Mürettebat Alman \\
\hline 1 Osman Oğlu İshak & \\
\hline
\end{tabular}

${ }^{38}$ BOA, DH. EUM. 5. Şube, 9/62. 
Trabzon'a yönelik Rus bombardımanlarından biri de 12 Ocak 1915 tarihinde gerçekleştirilmişti. Mevlid-i Nebevi’ye tesadüf eden bu günde Rus torpidosu Trabzon'a ateş açmış, Sülüklü' de henüz inşa halinde bulunan Türk tabyasından karşılık görünce çekilmişti. Aradan kısa bir süre geçtikten sonra, 25 Ocak 1915'te Trabzon ve Akçaabat önlerinde görülen Rus torpidoları, bir tür gözdağı verdikten sonra geri çekilmişlerdi. ${ }^{39}$

Bir diğer bombardıman Ocak ayında gerçekleştirilmiştir. Yalta bombardımanına karşılık olarak düşünülen bu saldırılar sonunda 31 Ocak'ta Trabzon bombalanmış, 9 Şubat'ta da Yoroz Burnu'ndaki gemiler batırılmıştır.

Rus kaynaklarına dayanılarak The Times gazetesine yansıyan bilgilere dayanarak Enis Şahin, Karadeniz'deki Rus filosuna ait torpido botların Trabzon' daki Türk bataryalarını bombardıman ve Akçaabat mıntıkasında iki köprüyü tahrip ettiklerini, Trabzon'da 3 ve Akçaabat'ta ise 50'den fazla Türk yelkenlisinin batırıldığını belirterek, bu saldırıları Rusların işgal öncesi bölgeye dair ön çalışmaları olarak ele almaktadır. ${ }^{40}$

Ruslar 1915 'in başlarından itibaren Şile'den Hopa'ya kadar gemi, kayık vb. bulunabilecek bütün iskeleleri bombardıman ederek buradaki deniz araçlarını batırdılar. Bu şekilde hem askeri deniz gücü yok edilmekte hem de lojistik destek sağlayacak araçlar etkisiz hale getirilmekteydi. ${ }^{41}$

\footnotetext{
${ }^{39}$ Lermioğlu, a.g.e., s. 233.

${ }^{40}$ Şahin, a.g.m., s. 121-122.

41 Rusların Karadeniz liman şehirlerini ve sahillerini bombalaması ve meydana gelen tahribatla ilgili yazışmalar ve kayıtlar için bkz., Başbakanlık Osmanlı Arşivi (BOA), Cevdet Askeriye, (C.AS) Gömlek Sıra No:47851.
} 
Rus bombardımanlarına tanıklık edenlerden biri olan Ali Şakir Ağanoğlu hatıratında Rus bombardımanını şöyle aktarmaktadır: ${ }^{42}$

"Daha 4-5 aylık bir çocuk olan ben, beşikten Rus toplarının gümbürtüsüyle uyanmaya başlamışım. İlk aylarda bütün kasaba halkı gemiler gelince (tabii Rus gemileri), yakın köylere, denize kapalı olan vadilere, derelere kaçıyormuş. Çoluk çocuk binlerce halk, her tarafi sarsan top gürültülerini dinleyerekten yine geceleri açıkta, kapıda, derede geçirmiş. Sayısız gemileriyle limana giden Ruslar günlerce kaldıklart olurmuş. Böyle günlerde kadınlar ve çocuklar, götürüldükleri yerlerde kalır, erkekler şehre inerler ve erkenden dönerlermiş. Rus gemileri giderse halk biraz nefes alır, evlerine dönermiş. Günün birinde kasabada yine bir haber yayılır "Gemi geliyor". Fakat bu sefer Yavuz veya Midilli'dir. Ufukta beyaz bir çizgi gibi süzülür, arkadan siyah bir iz bırakır, şarka doğru gidermiş. "Batum'u bombardımana gidiyor." Fakat neticesi fena. Herkes biliyor ki, birkaç saat bombardımandan sonra kaçıp gidecek ve onu yakalama imkanını bulamayan Rus filosu da hırsinı bizim köylerden çıkaracak. Halk artık biliyor ki, yarın sabah şafakla limana Rus gemileri dizilmiş bulunacak ve mermi savuracaktır. Akşamdan hazırlık yaparak (kasabadan) çıkmall. Günlerden bir gün büyük zırhlsst ve daha büyük gemileriyle Rus filosu limanımızdadır. $O$ ana kadar görülmedik müthiş bir surette bombardıman ediyorlar. Kasabamı halkı "ne büyük toplar..." diye o günleri ehemmiyetle naklederler. O bombardimanda limanda bulunan bütün sandal, sefine, ne varsa battyorlar. Birkaç gün kallyorlar ve gece sabaha kadar torpidoluyorlar limanı. Kordonlarla torpil dökerek kapattyorlar."

42 Ali Şakir Ağanoğlu'nun Yayımlanmamış Hatıratı. 


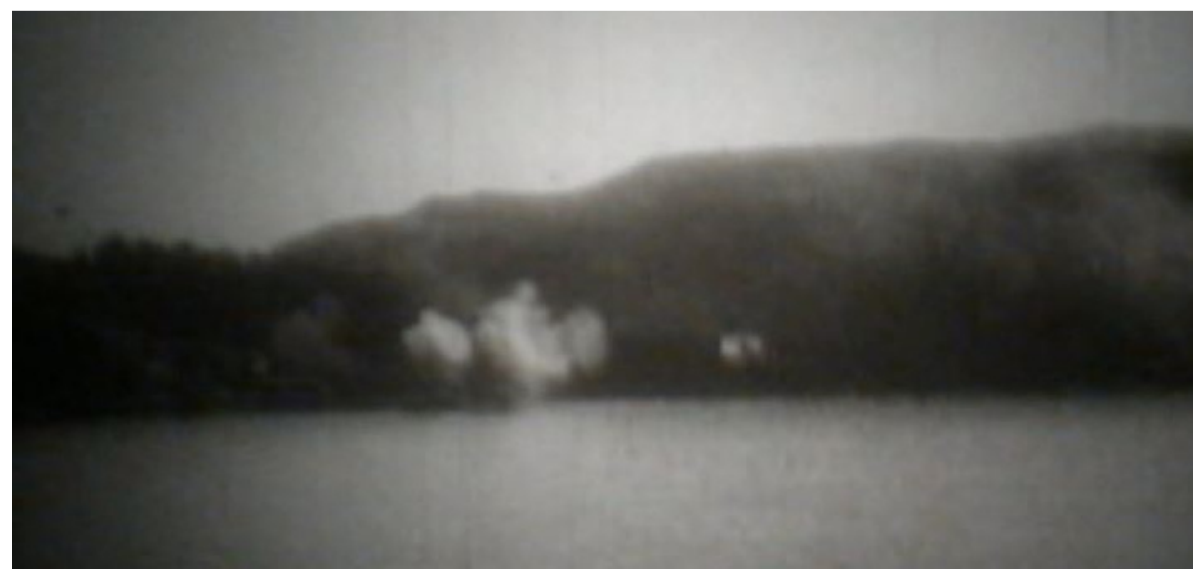

Rize sahillerinin bombalanması

Trabzon'un üçüncü ağır bombardımanı, 8 Şubat 1915 tarihinde gerçekleşmişti. Yoroz ve Boztepe'deki Türk gözcüleri tarafından Rus donanmasının görülmesi, şehirde önemli bir panik havası yaratmış, esnaf dükkanlarını kapatarak iç kesimlere doğru kaçmıştı. Sera üzerindeki Samsun adlı sandalla Kalanima'daki bir yelkenliyi batırarak limana doğru yaklaşan Rus torpidoları, limanda bulunan on üç parça çifte direk gemi başta olmak üzere batırarak ilerliyordu. Limandaki bütün kayıkları batırdıktan sonra Yoroz'a doğru hareketlenen Rus torpidoları, yeniden Akçaabat ve Trabzon'u bombalayarak Batum istikametine doğru gözden kaybolmuştu. Bu en ağır bombardıman ciddi zayiata yol açmıştı. İçkule ve İmaret Mahallesi'nde birçok ev yanmaya başlamış, Meydan'da bir subay şehit olmuş, bir çocuk yaralanmıştı. Kısa bir süre sonra ise Trabzon şehrini duman kaplamış, şehir adeta bir yangın yerine dönmüştü. Kesin bir rakam verilememekle birlikte Rusların bu bombardımanında Trabzon' da binden fazla ölü ile üç yüzü aşkın yaralı olduğu, halk arasında söyleniyordu. Bu büyük yıkıntıdan iki gün sonra, 10 Şubat 1915 'te, Rus gemileri yeniden Trabzon önlerinde görülerek kenti tehdit etmeye başlamışlar; şehir üzerinde dolaşan iki Rus deniz tayyaresi de bombardımana destek vermekteydi. ${ }^{43}$ Trabzon'un durumu her gün kötüleşiyordu. Bir yandan sürekli olarak cephelere asker gönderen Trabzon halkı, bir yandan da Rus donanmasının saldırı ve bombardımanlarına maruz kalmaktaydı. ${ }^{44}$

\footnotetext{
${ }^{43}$ Lermioğlu, a.g.e., s. 233-239.

${ }^{44}$ Goloğlu, a.g.e., s. 219-220.
} 
Hiç kuşku yok ki, Rus donanması tarafından Kasım 1914 tarihinden sonra Karadeniz'de bombalanan şehir, kasaba ve köyler Trabzon ve ilçelerinden ibaret değildi. Nitekim aşağıda Rus harp gemileri tarafından Zonguldak kazasına icra edilen bombardımandan dolayı vuku bulan hasarat, zarar ve ziyan,örnek olması bakımından verilmiştir.

\begin{tabular}{|c|c|c|c|c|}
\hline \multirow{2}{*}{$\begin{array}{l}\text { Mülahazat } \\
\text { Ameliyat mahalli harap olduğu }\end{array}$} & \multirow{2}{*}{$\begin{array}{l}\text { Hasar } \\
\text { Verenin } \\
\text { Esamisi } \\
\text { Şirket-i } \\
\text { Osmani }\end{array}$} & \multicolumn{2}{|c|}{$\begin{array}{l}\text { Tahmin Olunan Hasaratın } \\
\text { Nev'i Mikdarı Lira-yı } \\
\text { Osmanî }\end{array}$} & \multirow{2}{*}{$\begin{array}{c}\text { Sira } \\
\\
1\end{array}$} \\
\hline & & Fransız hastahanesi & 200 & \\
\hline Mevcud....telef olduğu & " & " & 450 & 2 \\
\hline $\begin{array}{l}18 \text { numrolu hanenin bahçesinin } \\
\text { duvarı }\end{array}$ & " & Hane & 5 & 3 \\
\hline $\begin{array}{l}\text { Su deposu ve boruların kısmen } \\
\text { harap olduğu }\end{array}$ & " & Depo & 2 & 4 \\
\hline $\begin{array}{l}5 \text { numrolu hane kismen rahnedar } \\
\text { olduğu }\end{array}$ & " & Hane & 15 & 6 \\
\hline $\begin{array}{l}\text { Hane-i mezkûrda şirket } \\
\text { memurunun telef olan eşyası }\end{array}$ & " & " & 20 & 7 \\
\hline $\begin{array}{l}\text { Üst kat ciheti ve bazı dolaplar } \\
\text { harap olduğu }\end{array}$ & " & Mekteb & 150 & 8 \\
\hline Bodrum duvarının harap olduğu & “" & Hane & 20 & 9 \\
\hline $\begin{array}{l}\text { Hane-i mezkûrda liman kumandanı } \\
\text { bulunmakla telef olan eşyası }\end{array}$ & " & " & 80 & 10 \\
\hline $\begin{array}{l}\text { Kumandan dairesi tavanı ve camı } \\
\text { tamamen harap ve iskelenin bazı } \\
\text { kısmı }\end{array}$ & " & Liman dairesi & 30 & 11 \\
\hline $\begin{array}{l}\text { Duvar ve pencereler ve döşeme } \\
\text { saçak ve kiremit }\end{array}$ & " & Yazıhane & 130 & 12 \\
\hline \multirow[t]{3}{*}{$\begin{array}{l}\text { Mühendis makinesi ve diğer alât } \\
\text { ve edevatın harap olduğu }\end{array}$} & " & " & 120 & 13 \\
\hline & & & & 14 \\
\hline & & & 1272 & \\
\hline
\end{tabular}


17 Kasım 1914 tarihinden itibaren başlayan Rus saldırısı sonucunda Trabzon, Hopa ve Şile arasındaki tüm iskeleler bombardıman edilmiştir. ${ }^{45}$ Rusya bu saldırılarında, bölgedeki Rum ve Ermeni azınlığın yardım ve rehberliğinden oldukça yararlanmıştır.

Bütün bu saldırılar Osmanlı Devleti tarafından takip edilmekte ve zararların tazminine çalışılmaktaydı. Nitekim Hükümet, sahil bombardımanlarının başladığı 1914 Kasım’ından 1915 yılı Haziran ayına kadar geçen sürede ortaya çıkan devlet, vakıf ve kişilere ait hasarların tespiti ve tazmin ettirilmede esas alınacak bedellerinin cetvel şeklinde hazırlanıp gönderilmesi için 22 Haziran 1915 'te tüm sahil vilayetlerine birer tahrirat göndermiştir. Valilikler tarafından hazırlanan cetvellerde bombardımanlardan zarar gören kişi, mal, eşya, bina ve deniz nakil araçlarının dökümü hasar bedelleriyle birlikte kuruş cinsinden verilmiştir. Bunlardan biri olan ve Trabzon vilayeti ve Canik livasına ait hasar tespit cetveli şöyledir: ${ }^{46}$

\section{Trabzon Vilayeti}

1 Sürmene ve Araklı Limanlarında bombardımanlarda hasar gören 45 adet özel ticari nakil aracı: 4.237 .000

1 Sürmene ve Araklı Limanlarında bombardımanlarda hasar gören özel binalar: 250.000

2 Trabzon'da hasar gören özel binalar: 9.332 .500

3 Şarlı Nahiyeli Mehmet Reis'in kayı̆̆ı ve eşyası: 11.955

4 Büyük Liman' da batırılan 5 gemi bedeli: 21.300

5 Tirebolu Limanı'nda batırılan 8 gemi bedeli: 25.630

6 Görele Limanı'nda batırılan 4 gemi bedeli: 40.000

\footnotetext{
45 Bingür Sönmez, "Sarıkamış Harekâtında Donanma Hareketleri”, 3. Deniz Harp Tarihi Semineri, Bildiriler Kitabl, 19-21 Nisan 2006, Gölcük/ Kocaeli, Ankara 2006; Cemal GüvenMustafa Zenginbaş, "Kafkas Cephesi'nin Karadeniz'den Takviyesine İlk Darbe: Rus Filosu Tarafından Zonguldak Bombardımanı ve Askerî Nakliye Gemilerinin Batırılması Hadisesi,” I. Uluslararası Karadeniz Kültür Kongresi, Karabük 2013, s. 285-297; Mehmet Temel, "İtilaf Devletlerinin Osmanlı Kıyı Yerleşmelerine Yaptığı Saldırılar ve Mütekabiliyet Esasına Göre Osmanlı Devleti'nin Aldığı Önlemler", Ege Üniversitesi Tarih İncelemeleri Dergisi, C. XXIV, S. 1, Temmuz 2009, s. 119.

${ }^{46}$ Temel, a.g.m., s. 136-137.
} 
715 Kanun-u sani bombardımanında Trabzon Limanı'nda hasar gören 10 gemi: 845.500

8 Görele Limanı'nda batırılan 7 gemi bedeli: 354.940

9 Polathane Limanı'nda batırılan 26 gemi bedeli: 1.165.027

10 Büyük Liman'da batırılan 7 gemi bedeli: 66.247

11 Hopa Kazası sahillerinde meydana gelen hasarlar: 5.742.500

12 Atina, Ardeşen ve Gora'daki hanelerde meydana gelen hasarlar: 84.900

13 Atina, Giresun, Kastel, Arkotil ve Zarha' daki hanelerde meydana gelen hasarlar: 2.160.200

14 Atina, Denek, Miladis'te meydana gelen hasarlar: 696.900

15 Ordu kaymakamının gönderdiği cetvel muhteviyatı: 54.909

16 Rize Limanı'ndaki hasar: 475.409

17 Hopa'nın Bucak Köyü’nde Şevki Efendi’nin hane ve eşyası:75.000

26.040.417

\section{Canik Livası}

18 Samsun Mutasarrıfının gönderdiği cetvel muhteviyatı

(Ahaliden 11 şehit, 7 esir/ Samsun ve ilçelerinin 1915 yılı hasar tespit tutarı 1.562.538 kuruş buna 1916 Fatsa bombardımanı eklendiğinde 1.751.346 kuruşu buluyordu. ${ }^{47}$ ) $\mathbf{1 6 7 . 2 7 5}$

Belgeden de anlaşılacağı üzere, Trabzon Vilayeti hudutları dahilinde Rus bombardımanları nedeniyle meydana gelen maddi zayiat oldukça yüksek bir meblağ oluşturmaktadır.

Karadeniz sahilleri 1915 yılı boyunca Rus saldırılarına maruz kalmıştır. $\mathrm{Bu}$ durum yerel idareciler tarafından sürekli olarak İstanbul'a iletilmiştir. Pek çok kez bombardımanlar hakkında bir günde birkaç telgraf çekildiği gibi, gemilerin görülmesi durumunda dahi bilgi verilmekteydi. Nitekim bunlardan biri, Trabzon Valisi Cemal Azmi Bey tarafından, Batum istikametinden gelen iki Rus kruvazörünün 10 Ocak 1915'te, Hopa

\footnotetext{
${ }^{47}$ Canik Livası'ndaki savaş durumu ile ilgili detaylı bilgi için bkz., Osman Köse, "Rusların Samsun'u Bombardımanı (1915)”, OMÜ Eğitim Fakültesi Dergisi, 11, Samsun 1999.
} 
kasabasını bombardıman ettiği şeklinde merkeze iletilen bir telgrafa konu olmuştur. ${ }^{48}$ Bir diğeri ise 28 Ocak 1915 tarihli telgraftı. ${ }^{49}$

8-10 Şubat 1915 tarihlerinde yine Vali Cemal Azmi Bey'in çektiği telgrafta, Rize'de meydana gelen bazı hadiseler özetlenmekteydi: Öğleden sonra dört buçukta Atina tarafından gelen dört bacalı, iki direkli iki Rus torpidosu Rize'yi geçerek Arkotil mevkiinde bir sandalı tahrip etmiş daha sonra askeri kışla, depo ve askerlik şubesinin misafirhanesine yüzden fazla mermi atmıştır. Epeyce bir tahribattan sonra bu defa beş on mermi de Askoroz mevkiine atılmış, can kaybı olmamıştır.

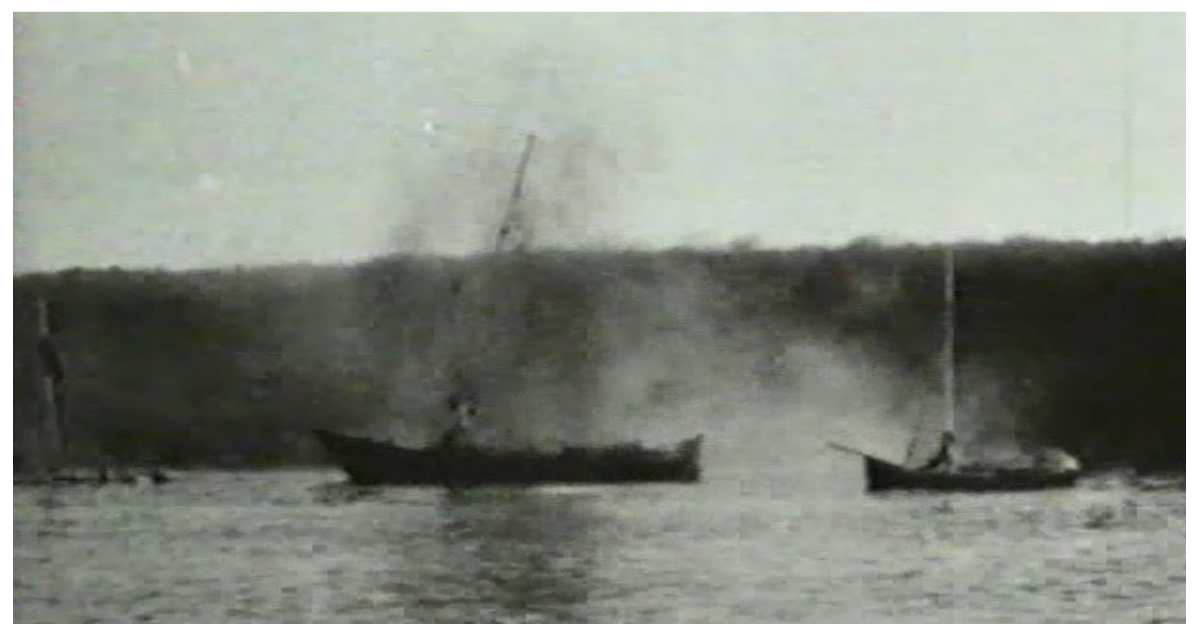

Sahildeki Türk kayıklarının bombalanması ve batırılması

Cemal Azmi Bey'in çektiği bu telgrafta Akçaabat Kaymakamlığının verdiği bilgiler de yer almış, düşman filosundan iki torpido muhribinin kara ve denizde verdiği hasarlar sıralanmıştır. Buna göre Hacı Beşir mevkiindeki değirmenin yanında bulunan şose köprünün iki ayağ zedelenmiştir. Sera Deresi ağzında bulunan Civanlı Haşim oğlu Hasan Reisin kayığı batmış, aynı mevkide Kalcızade Süleyman Bey'in hanesinin alt kısmı tahrip olmuştur. Yine Saldı oğlu Ali Osman Reisin kotrası, Sera Deresi sahilinde bulunan Samsun motoru, Rizeli Ahmet Reisin portakal

${ }^{48}$ BOA, DH.EUM. 5. Şube, $9 / 62$.

${ }^{49} B O A, D H$. EUM. 5. Şube, 9/62. 
yüklü kayığı da batmıştır. Sera ile Hacı Beşir arasındaki şose köprüye de üç mermi isabet etmiş ve ciddi hasar meydana gelmiştir. ${ }^{50}$

Rus saldırıları 25 Şubat 1915 tarihinde Sinop'un bombardıman edilmesi ile sürdü. Diğer sahil şehirlerinde olduğu gibi sivil gemilerin zarar görmesi tazminat taleplerini de beraberinde getiriyordu. Nitekim bu bombardıman esnasında gemilerinin battığı iddiasıyla Delez oğlu Osman ve Edirneli Müezzinzade Hacı Mehmet ve Hacı Yakub imzalarıyla dilekçeler sunulmuş ve tazminat istenmiştir. Bunun için Dâhiliye Nezareti tarafından, mahalli tazminat-1 harbiye komisyonunca inceleme yapılması kararlaştırılmıştır. Yapılan incelemede bombardımanda yara alan ve daha sonra batan geminin nakil işini tamamladığı ve ücretini aldığı anlaşılmış, askeri görev sırasında battığı iddiasıyla istenen tazminat reddedilmiştir. Ancak hususi tazminat konusu olabileceği düşüncesiyle keşif sonrası gemiye 1200 lira kıymet belirlenmiştir. ${ }^{51}$

Benzer şekilde diğer bir kaptan "Nimet-i Hüda" adında ve 63 tonilato büyüklüğündeki gemisinin Sinop limanında bulunduğu sırada Rus saldırısı sonrası battı̆̆ 1 ve aileleriyle birlikte mağdur oldukları gerekçesi dolayısıyla 700 lira yardım talebinde bulunmuştur. ${ }^{52}$

30 Mart 1915 Bolu Mutasarrıf Vekilinin Dâhiliye Nezaretine gönderdiği yazıda Zonguldak'ın bombalandığına dair bilgiler mevcuttur. $\mathrm{Bu}$ saldırıda Zonguldak merkezde 13 hanenin tamamen ve 6 hane ile bir dükkân ve bir otelin de kısmen hasara uğradığı ve Hükümet Konağı civarında bir kiremit mağazasına atılan bombadan mağazada bulunan zift ve yağlı boyaların yangına sebebiyet verdiği; Kozlu'da 15 hanenin önemli derecede ve Kilimli'de maden idaresiyle demirhane ve telgrafhanenin nispeten hafif bir halde harap olduğu bilgisi verilmektedir. Ayrıca Şirket-i Osmaniye'nin maden direklerinin bir bölümü de parçalamıştır. ${ }^{53}$

17 Aralık 1915 tarihinde saat on yedide on bir parçadan mürekkep Rus harp gemileri Sinop civarına gelerek ve bunlardan üçü de limana girerek fasılalarla attıkları yirmi altı mermi ile iki kayık ve Yunan bandıralı bir vapuru batırmışlardır. Saldırı sırasında karantina idaresi tamamen ve iki hane de kısmen tahrip olmuş, bir eczacı hafif bir surette kolundan yaralanmıştır. ${ }^{54}$

${ }^{50}$ BOA, DH. EUM. 5. Sube, $9 / 62$.

${ }^{51}$ BOA, DH. EUM , 5. Şube, 9/62.

${ }^{52}$ BOA, DH. EUM. 5. Şube, 9/62.

${ }^{53}$ BOA, DH.EUM. 5. Şube, 9/62; BOA, DH.EUM. 5. Şube, 13/34.

${ }^{54}$ BOA, DH.EUM. 5. Şube, 9/62. 
Rusların Karadeniz sahilini bombardıman süreçlerinde en önemli konulardan birisi askeri bilgi toplamaktı. Ancak bu durum can güvenliği açısından sakıncalıydı. Bu bakımdan Trabzon ve Kastamonu vilayetleriyle, Bolu, İzmit ve Canik mutasarrıflıklarına bilgi verilmiş, balık tutulması yasaklanmıştır. Zira belgelerden anlaşılacağı üzere balıkçılar ve çocuklar Ruslar tarafından görülmekte ve hedef haline gelmekteydi.

$\mathrm{Bu}$ amaçla gönderilen bir telgrafta Lazistan Sancağında da balıkçılığın tamamen yasaklandığı, merkez ve diğer mülhakat vilayetinde de 20 yaşından aşağı olanların kati surette balık tutmaktan men edilmesi ve liman dairelerinden vesika almak şartıyla bütün balıkçıların sahilden 1 milden fazla açığa gitmemesi tedbiri alınmıştır. ${ }^{55}$

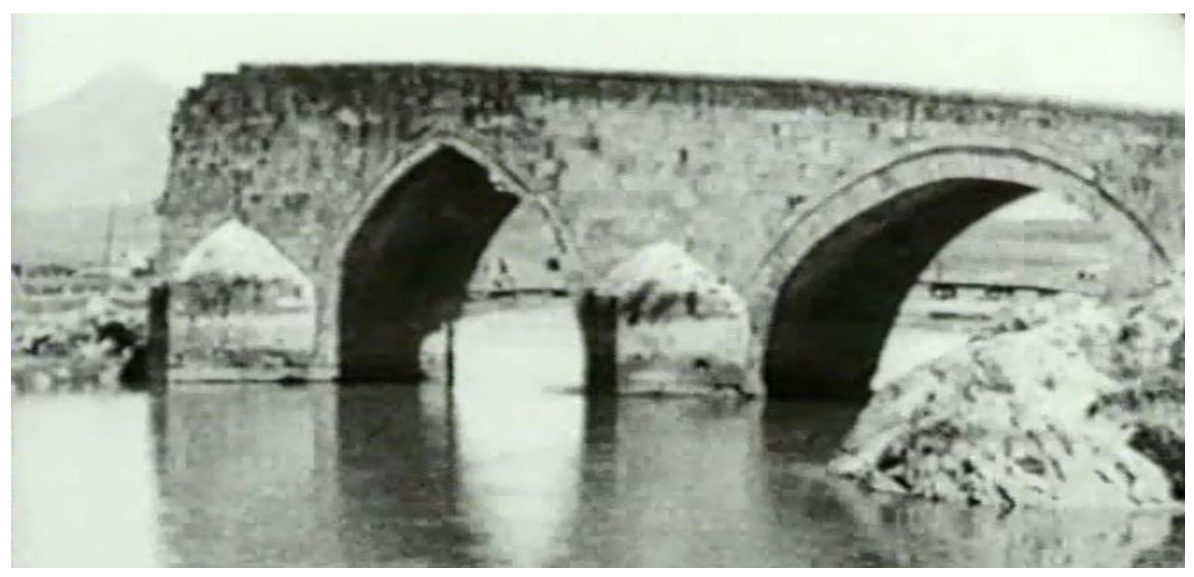

Rus bombalardan yıkılmış bir köprü

\section{Sonuç}

I. Dünya Savaşı sırasında Alman Genelkurmayı ile ortak hazırlanan savaş stratejisi gereği Kafkasya'dan Rusya'ya taarruz eden Osmanlı ordularının lojistik desteği Karadeniz üzerinden, özellikle Trabzon limanı vasıtasıyla sağlanmaktaydı. Savaşın başlangıcıyla birlikte Rus donanması Osmanlı Devleti'nin Karadeniz'deki limanlarını dolayısıyla Trabzon'u bombalamaya başlamıştır. Kafkas Cephesi'nin çökmesi (Sarıkamış Savaşı'nın kaybedilmesi) ve üstünlüğün Rus ordusuna geçmesiyle denizden ve karadan Rus ordusunun kıskacına giren Doğu Karadeniz Bölgesi, 191618 yılları arasında çok dramatik olaylara sahne olmuştur. Bunlardan en önemlisi bölge Müslümanlarının batı illerine doğru başlatmış oldukları

${ }^{55}$ BOA, DH.EUM. 5. Şube, 9/62; BOA, DH.EUM. 5. Şube, 13/34. 
kitlesel göç olayıdır. Bölgede "Muhacirlik" olarak adlandırılan bu dönem halkın sosyal hafızasında derin izler bırakmış ve sözlü kültürle günümüze kadar ulaşmıştır. ${ }^{56}$

18 Nisan 1916'da Trabzon'un Rus işgaline uğraması Doğu Karadeniz Bölgesi'nde yaşayan Türk insanı için çok sıkıntılı bir dönem başlatmıştır. 1461 tarihindeki fetihten sonra aralıksız 4.5 asır Türk hakimiyetinde olan Trabzon ilk kez işgale maruz kalıyordu. Doğu Anadolu Bölgesi'nde 19. yüzyılda yaşanmış olan Rus işgali ve beraberinde gelen mezalim sözlü kültür ortamında dilden dile taşınan bir olguydu ve şimdi Trabzon da bu olguyla karşı karşıya kalıyordu. Buna bir de Rum ve Ermenilerin ihanet ve zulmünü eklersek tahammül edilemeyecek bir durum meydana gelmekteydi. $\mathrm{Bu}$ olgular ve Türk insanının içselleştirdiği "devletsiz yaşayamama" durumu bölgede yaşayan halkı muhacirliğe yöneltti ve yüz binlerce insan yollara döküldü. İki yılı aşkın bir süre devam eden muhaceret; Rusya'da Bolşevik Devrimin meydana gelmesi; 1918'in başından itibaren Rus askerinin geri çekilmesi ve 24 Şubat 1918'de Trabzon'un kurtuluşu ile birlikte sona ermiştir. Rusların geri çekilmesi ile birlikte Osmanlı Devleti'nin işgale uğramamış vilayetlerine sığınmış olan Trabzon muhacirlerinden sağ kalanlarının bir kısmı geri dönmüş, bir kısmı da değişik vilayetlerde iskân edilmiştir.

Muhacirlik kadar Doğu Karadeniz Bölgesi'ni etkileyen başka bir sosyal olay yoktur. Bu hadise yakın dönem tarihimizde bölgenin Türk ahalisi için bir milat ve buna bağlı olarak sosyal hafızada gelişen bir halk takvimi başlangıcıdır. $\mathrm{O}$ dönemi yaşamış olan insanlar kendi yaşlarını hesaplarken bu olgudan hareket ederler ve doğum tarihlerini tespit ederlerdi.

Trabzon halkını olduğu kadar bölge insanını da bu kadar derinden etkileyen, "belini büken" muhacirliğin belgesel çalışmaları yapılmalı, romanları yazılıp edebiyatı oluşturulmalıdır.

\footnotetext{
${ }^{56}$ Mediha Kayra, Hoşça Kal Trabzon, Bir Kız Çocuğunun Günlüğünden Birinci Dünya Savaşı'nda Anadolu, (Günümüz Türkçesine Çeviren, Cahit Kayra), Dünya Kitapları, İstanbul 2005; Arzu Türkmen, "Remembering through Material Culture: Local Knowledge of Past Communities in a Turkish Black Sea Town", Middle Eastern Studies, Vol. 39, No: 2, London, April 2003, s.179-193.
} 


\section{KAYNAKÇA}

Ali Şakir Ağanoğlu'nun Yayımlanmamış Hatıratı.

BOA, DH. EUM. 5. Şube, 9/62.

BOA, DH.EUM. 5. Şube, 13/34.

BíLGiN, Mehmet, Rus İsgalinde Trabzon Direnişi, Trabzon 2008. 2011.

ÇAKMAK, Fevzi, Büyük Harpte Şark Cephesi Harekatı, İstanbul

GOLOĞLU, Mahmut, Trabzon Tarihi, Trabzon 2013.

GONÇAROV, V., Deystviya Primorskogo Otryada Kavkaskoy Armii, Ast-tranzitkniga, Moskova 2004.

GÜVEN, Cemal-ZENGINBAŞ, Mustafa, “Kafkas Cephesi'nin Karadeniz'den Takviyesine İlk Darbe: Rus Filosu Tarafından Zonguldak Bombardımanı ve Askerî Nakliye Gemilerinin Batırılması Hadisesi," I. Uluslararası Karadeniz Kültür Kongresi, Karabük 2013.

KAYRA, Mediha, Hoşça Kal Trabzon, Bir Kız Çocuğunun Günlüğünden Birinci Dünya Savaşı'nda Anadolu, (Günümüz Türkçesine Çeviren, Cahit Kayra), Dünya Kitapları, İstanbul 2005.

KÖSE, Osman, "Rusların Samsun'u Bombardımanı (1915)", OMÜ Eğitim Fakültesi Dergisi, 11, Samsun 1999.

LERMIOĞLU, Muzaffer, Akçaabat- Akçaabat Tarihi ve Birinci Genel Savaş - Hicret Hatıralarl, İstanbul 2012.

LERMIOĞLU, Muzaffer, Akçaabat Tarihi ve Birinci Genel SavaşHicret Hatıraları, İstanbul 1949.

Manchester Guardian, 20 Nisan 1916, s. 14.

Manchester Guardian, 3 Nisan 1916, s. 10.

ÖKSÜZ, Hikmet-USTA, Veysel, Mustafa Reşit Tarakçıŏlu, Hayatı, Hatıratı ve Trabzon'un Yakın Tarihi, Trabzon 2008.

ÖZDEMIR, Yavuz, Bir Savaşın Bilinmeyen Öyküsü, Sarıkamış Harekâtı, Erzurum 2003.

ÖZEL, Sebahattin, Milli Mücadelede Trabzon, Ankara 1991. 
SÖNMEZ, Bingür, "Sarıkamıs Harekâtında Donanma Hareketleri”, 3. Deniz Harp Tarihi Semineri, Bildiriler Kitabı, 19-21 Nisan 2006, Gölcük/ Kocaeli, Ankara 2006.

ŞAHIN, Enis, “İngiliz The Times Gazetesi'ne Göre Trabzon'un Ruslar Tarafından İşgali”, Uluslararası Karadeniz İncelemeleri Dergisi, S. 1, Güz 2006.

TARAKÇIOĞLU, Mustafa Reşit, Trabzon'un Yakın Tarihi, Trabzon 1986.

TEMEL, Mehmet, "İtilaf Devletlerinin Osmanlı Kıyı Yerleşmelerine Yaptığı Saldırılar ve Mütekabiliyet Esasına Göre Osmanlı Devleti' nin Aldığg Önlemler", Ege Üniversitesi Tarih Incelemeleri Dergisi, C. XXIV, S. 1, Temmuz 2009.

TÜRKMEN, Arzu, "Remembering Through Material Culture: Local Knowledge of Past Communities in a Turkish Black Sea Town", Middle Eastern Studies, Vol.39, No:2, London, April 2003. 
